\title{
Pedobacter ginsengisoli sp. nov., a DNase- producing bacterium isolated from soil of a ginseng field in South Korea
}

\author{
Leonid N. Ten, ${ }^{1,2} \dagger$ Oing-Mei Liu, ${ }^{1} \dagger$ Wan-Taek Im, ${ }^{1}$ Myungjin Lee, ${ }^{1}$ \\ Deok-Chun Yang ${ }^{3}$ and Sung-Taik Lee ${ }^{1}$ \\ ${ }^{1}$ Department of Biological Sciences, Korea Advanced Institute of Science and Technology, \\ 373-1, Guseong-dong, Yuseong-gu, Daejeon 305-701, Republic of Korea \\ ${ }^{2}$ National University of Uzbekistan, Students town, Tashkent, 700-174, Uzbekistan \\ ${ }^{3}$ Department of Oriental Medicinal Material and Processing College of Life Science, Kyung \\ Hee University, 1 Seocheon, Kihung Yongin, Kyunggi 449-701, Republic of Korea
}

Correspondence Wan-Taek Im wandra@kaist.ac.kr
The genus Pedobacter was first described by Steyn et al. (1998) and currently comprises species isolated from soil (Pedobacter heparinus, $P$. africanus, $P$. saltans and $P$. sandarakinus), from a commercial nitrifying inoculum (Pedobacter caeni), from fish (Pedobacter piscium), from a glacier in the Tyrolean Alps (Pedobacter cryoconitis) and from glacial water in the Himalayan mountains of India (Pedobacter himalayensis) (Steyn et al., 1998; Margesin et al., 2003; Shivaji et al., 2005; Vanparys et al., 2005; Yoon et al., 2006). Two further species of the genus, Pedobacter roseus and Pedobacter aquatilis, have been described recently (Gallego et al., 2006; Hwang et al., 2006). The members of the genus Pedobacter have the following characteristics: they are Gram-negative rods, they are obligately aerobic, positive for catalase, oxidase and heparinase, they may or may not show gliding motility, they are negative for urease, lipase,

†These authors contributed equally to this work.

The GenBank/EMBL/DDBJ accession number for the 16S rRNA gene sequence of strain Gsoil $104^{\top}$ is AB245371. gelatinase, indole production and nitrate reduction and they contain iso- $\mathrm{C}_{15: 0}$, iso- $\mathrm{C}_{15: 0} 2-\mathrm{OH}$, iso- $\mathrm{C}_{15: 0} 3-\mathrm{OH}, \mathrm{C}_{16: 0}$, $\mathrm{C}_{16: 1} \omega 5 c, \mathrm{C}_{16: 1} \omega 7 c, \mathrm{C}_{16: 0} 3-\mathrm{OH}$, iso- $\mathrm{C}_{17: 0} 3-\mathrm{OH}$ and iso$\mathrm{C}_{17: 1} \omega 9 c$ fatty acids (Steyn et al., 1998).

During the course of a study on the culturable aerobic and facultative anaerobic bacterial community living in the soil of a ginseng field in Pocheon Province (South Korea), a large number of novel bacterial strains were isolated. In this study, we have characterized one of these isolates, strain Gsoil $104^{\mathrm{T}}$. Our phenotypic, genotypic, chemotaxonomic and phylogenetic analyses have established the affiliation of the isolate to the genus Pedobacter. The data obtained also suggest that the isolate represents a novel species of the genus Pedobacter.

Strain Gsoil $104^{\mathrm{T}}$ was originally isolated from a soil sample from a ginseng field in Pocheon Province (South Korea). The soil sample was suspended in $50 \mathrm{mM}$ phosphate buffer $(\mathrm{pH} 7 \cdot 0)$ and spread on plates of $1 / 5$-strength modified R2A agar $(0 \cdot 25 \mathrm{~g}$ tryptone, $0 \cdot 25 \mathrm{~g}$ peptone, $0 \cdot 25 \mathrm{~g}$ yeast extract, 
$0 \cdot 125 \mathrm{~g}$ malt extract, $0 \cdot 125 \mathrm{~g}$ beef extract, $0 \cdot 25 \mathrm{~g}$ Casamino acids, $0.25 \mathrm{~g}$ soytone, $0.5 \mathrm{~g}$ glucose, $0.3 \mathrm{~g}$ soluble starch, $0.2 \mathrm{~g}$ xylan, $0.3 \mathrm{~g}$ sodium pyruvate, $0.3 \mathrm{~g} \mathrm{~K}_{2} \mathrm{HPO}_{4}, 0.05 \mathrm{~g}$ $\mathrm{MgSO}_{4}, 0 \cdot 05 \mathrm{~g} \mathrm{CaCl}_{2}$ and $15 \mathrm{~g}$ agar l $^{-1}$ ) after serial dilution with $50 \mathrm{mM}$ phosphate buffer $(\mathrm{pH} \mathrm{7 \cdot 0})$. The plates were incubated at $25^{\circ} \mathrm{C}$ for 1 month. Single colonies on the plates were purified by transferring them onto new plates and were incubated once again on modified R2A or on half-strength modified R2A. Purified colonies were tentatively identified from partial sequences of the 16S rRNA gene (Im et al., 2005). Gsoil $104^{\mathrm{T}}$ was one of the dominant isolates on the modified R2A agar plates under aerobic conditions. It was routinely cultured on $\mathrm{R} 2 \mathrm{~A}$ agar at $30^{\circ} \mathrm{C}$ and was maintained as a glycerol suspension $(20 \%, \mathrm{w} / \mathrm{v})$ at $-70^{\circ} \mathrm{C}$.

A nearly-complete 16S rRNA gene sequence of strain Gsoil $104^{\mathrm{T}}$ was determined as described below. DNA was extracted using a commercial genomic DNA-extraction kit (Core Biosystem) and PCR-mediated amplification of the 16S rRNA gene and sequencing of the purified PCR product were carried out according to Kim et al. (2005). Full sequences of the $16 \mathrm{~S}$ rRNA gene were compiled using SeqMan software (DNASTAR). The 16S rRNA gene sequences of related taxa were obtained from the GenBank database. Multiple alignments were performed with the CLUSTAL_X program (Thompson et al., 1997) and gaps were edited in the BioEdit program (Hall, 1999). Evolutionary distances were calculated using the Kimura two-parameter model (Kimura, 1983). Phylogenetic trees were constructed by using the neighbour-joining method (Saitou \& Nei, 1987) and the maximum-parsimony method (Fitch, 1971) using the MEGA3 program (Kumar et al., 2004) with bootstrap values based on 1000 replications (Felsenstein, 1985).

Comparative 16S rRNA gene sequence analyses of strain Gsoil $104^{\mathrm{T}}$ (1430 bp) showed that the strain is phylogenetically affiliated to Pedobacter species. The phylogenetic tree (Fig. 1) based on the neighbour-joining algorithm showed strain Gsoil $104^{\mathrm{T}}$ to have a distinct phylogenetic position within the genus Pedobacter. The almost-complete 16S rRNA gene sequence of strain Gsoil $104^{\mathrm{T}}$ exhibits similarity levels of $\leqslant 97 \%$ with respect to the type strains of six Pedobacter species with validly published names, namely $P$. africanus DSM $12126^{\mathrm{T}}(97 \cdot 0 \%)$, P. caeni LMG $22862^{\mathrm{T}}$
(96.9\%), P. cryoconitis DSM $14825^{\mathrm{T}}$ (96.8\%), P. heparinus DSM $2366^{\mathrm{T}}(96 \cdot 6 \%)$, P. piscium DSM $11725^{\mathrm{T}}(96 \cdot 5 \%)$ and P. himalayensis JCM $12171^{\mathrm{T}}(96 \cdot 4 \%)$. The levels of $16 \mathrm{~S}$ rRNA gene sequence similarity with $P$. sandarakinus KCTC $12559^{\mathrm{T}}$ and P. saltans DSM $12145^{\mathrm{T}}$ are only $93 \cdot 7$ and $90 \cdot 1 \%$, respectively. In the phylogenetic tree constructed, strain Gsoil $104^{\mathrm{T}}$ is clearly separated from $P$. sandarakinus and $P$. saltans as well as from $P$. roseus $\mathrm{CL}-\mathrm{GP} 80^{\mathrm{T}}$ and $P$. aquatilis AR107 ${ }^{\mathrm{T}}$. Strain Gsoil $104^{\mathrm{T}}$ and Pedobacter species (except $P$. saltans) form a monophyletic clade with a high bootstrap value $(100 \%)$ that was supported by the neighbour-joining and maximum-parsimony methods employed in this study for phylogenetic tree construction. The generally accepted criteria for delineating bacterial species state that strains with a DNA-DNA relatedness value below $70 \%$ (as measured by hybridization), or strains with 16S rRNA gene sequence dissimilarity above $3 \%$, are considered as belonging to separate species (Wayne et al., 1987; Stackebrandt \& Goebel, 1994; Stackebrandt et al., 2002). On this basis, our data indicate that strain Gsoil $104^{\mathrm{T}}$ is highly likely to represent a novel species of the genus Pedobacter.

The Gram reaction was determined using the non-staining method, as described by Buck (1982). Cell morphology was observed under a Nikon light microscope at $\times 1000$, using cells grown for 6 days at $25^{\circ} \mathrm{C}$ on R2A agar. Catalase activity was determined from bubble production in $3 \%(\mathrm{v} / \mathrm{v}) \mathrm{H}_{2} \mathrm{O}_{2}$ and oxidase activity was determined using $1 \%(\mathrm{w} / \mathrm{v})$ tetramethyl- $p$-phenylenediamine. To determine the assimilation of single carbon sources, a defined liquid medium containing basal salts was used, as follows $\left(\mathrm{g} \mathrm{l}^{-1}\right)$ : $\mathrm{K}_{2} \mathrm{HPO}_{4}$, $1.8 \mathrm{~g} ; \mathrm{KH}_{2} \mathrm{PO}_{4}, 1.08 \mathrm{~g} ; \mathrm{NaNO}_{3}, 0.5 \mathrm{~g} ; \mathrm{NH}_{4} \mathrm{Cl}, 0.5 \mathrm{~g} ; \mathrm{KCl}$, $0 \cdot 1 \mathrm{~g} ; \mathrm{MgSO}_{4}, 0 \cdot 1 \mathrm{~g}$; and $\mathrm{CaCl}_{2}, 0 \cdot 05 \mathrm{~g}$. A vitamin solution (Widdel \& Bak, 1992), a trace element solution (SL-10; Widdel et al., 1983) and a selenite/tungstate solution (Tschech \& Pfennig, 1984) were added to this medium, and the $\mathrm{pH}$ was adjusted to $6 \cdot 8$. This liquid medium was poured into 96 wells and $25 \times$ stock filter-sterilized carbon sources were added to each well. The wells were incubated at $25^{\circ} \mathrm{C}$ for up to 7 days and were examined visually for growth. Negative-control wells did not contain any carbon sources. Positive-control wells comprised cultures grown in R2A broth. Some physiological characteristics were determined with API 20E galleries, according to the instructions of the manufacturer (bioMérieux). Anaerobic growth and

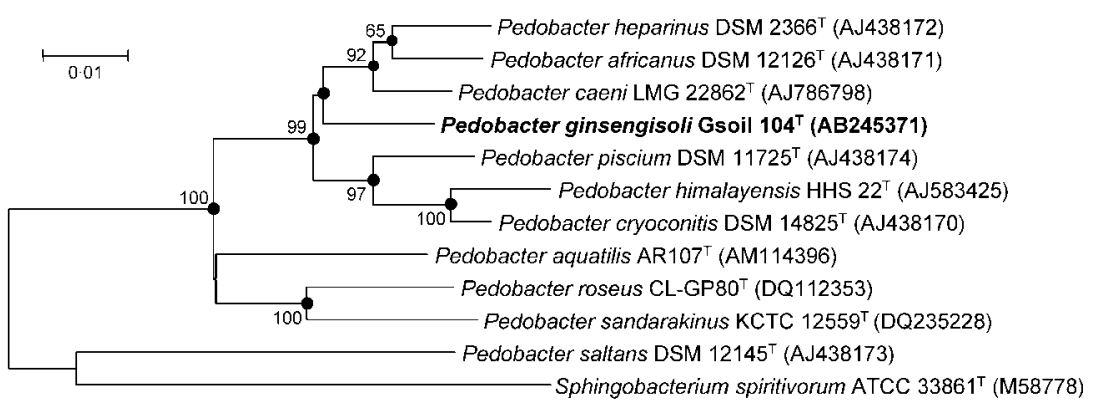

Fig. 1. Phylogenetic dendrogram, obtained by neighbour-joining clustering of 16S rRNA gene sequences, showing phylogenetic relationships between strain Gsoil $104^{\top}$, species of the genus Pedobacter and Sphingobacterium spiritivorum. Bootstrap values (expressed as percentages of 1000 replications) greater than $60 \%$ are shown at branch points. Filled circles indicate that the corresponding nodes were also recovered in the tree generated using the maximum-parsimony algorithm. Bar, 0.01 substitutions per nucleotide position. 
anaerobic reduction of nitrate as the final electron acceptor were determined in serum bottles containing R2A broth to which thioglycolate $\left(1 \mathrm{~g} \mathrm{l}^{-1}\right)$ had been added and in which the upper air layer had been replaced with $\mathrm{N}_{2}$; for determination of nitrate reduction, nitrate was added as $\mathrm{KNO}_{3}$ at a concentration of $10 \mathrm{mM}$. Aerobic reduction of nitrate was later confirmed by inoculation into serum bottles $(25 \mathrm{ml})$ containing $12 \mathrm{ml} \mathrm{R} 2 \mathrm{~A}$ media, with nitrate being added as $\mathrm{KNO}_{3}$ at $10 \mathrm{mM}$. The reduction of nitrate was monitored by ion chromatography on a model 790 personal IC (Metrohm) equipped with a conductivity detector and an anion exchange column (Metrosep Anion Supp 4; Metrohm). The degradation of DNA (using DNase agar from Scharlau, supplemented with $1 \mathrm{M} \mathrm{HCl}$ ), casein, chitin, starch (Atlas, 1993), lipid (Kouker \& Jaeger, 1987), xylan and cellulose (Ten et al., 2004) was also investigated; reactions were read after 7 days. Growth at different temperatures $\left(4,15,25,30,37\right.$ and $\left.42^{\circ} \mathrm{C}\right)$ and various $\mathrm{pH}$ values $(\mathrm{pH} 4 \cdot 5-10 \cdot 0$, using increments of $0.5 \mathrm{pH}$ units) was assessed after 5 days incubation. Salt tolerance was tested on R2A medium supplemented with $1-10 \%(\mathrm{w} / \mathrm{v}) \mathrm{NaCl}$ after 5 days incubation. Growth on nutrient agar, trypticase soy agar (Difco) and MacConkey agar was also evaluated, at $25^{\circ} \mathrm{C}$.

The cells of strain Gsoil $104^{\mathrm{T}}$ were Gram-negative, aerobic, non-spore-forming, non-motile and rod-shaped. After 6 days incubation at $25^{\circ} \mathrm{C}$ on $\mathrm{R} 2 \mathrm{~A}$, colonies were $2-5 \mathrm{~mm}$ in diameter, smooth, convex, round, glossy and white. On R2A agar, the optimal growth temperature for Gsoil $104^{\mathrm{T}}$ was $25^{\circ} \mathrm{C}$; the strain was able to grow at $4-30^{\circ} \mathrm{C}$, but not at $37^{\circ} \mathrm{C}$. The strain grew between $\mathrm{pH} 5.0$ and 8.5 , with an optimum between $\mathrm{pH} 6 \cdot 5$ and $7 \cdot 5$. Growth occurred in the absence of $\mathrm{NaCl}$ and in the presence of $1 \%(\mathrm{w} / \mathrm{v}) \mathrm{NaCl}$, but not in the presence of $2 \%(\mathrm{w} / \mathrm{v}) \mathrm{NaCl}$. The biochemical characteristics of strain Gsoil $104^{\mathrm{T}}$ were found to be similar to those reported for members of the genus Pedobacter (Steyn et al., 1998), i.e. positive for oxidase and catalase, able to assimilate D-mannose, D-glucose, $\mathrm{N}$ acetyl-D-glucosamine and amygdalin, negative for $\mathrm{H}_{2} \mathrm{~S}$ production, indole production, urease, lipase and nitrate reduction and unable to produce acid from a large number of substrates. The phenotypic and chemotaxonomic characteristics that differentiate strain Gsoil $104^{\mathrm{T}}$ from related Pedobacter species are listed in Table 1. In contrast to all other Pedobacter species, Gsoil $104^{\mathrm{T}}$ does not hydrolyse aesculin.

For measurement of the $\mathrm{G}+\mathrm{C}$ content of chromosomal DNA, the genomic DNA of the strain was extracted and purified as described by Moore \& Dowhan (1995) and enzymically degraded into nucleosides. The $\mathrm{G}+\mathrm{C}$ content of the DNA was then determined as described by Mesbah et al. (1989), using reversed-phase HPLC. Isoprenoid quinones were extracted with chloroform/methanol $(2: 1$, $\mathrm{v} / \mathrm{v})$, evaporated under a vacuum and re-extracted in $\mathrm{n}$ hexane/water $(1: 1, \mathrm{v} / \mathrm{v})$. The crude quinone in $\mathrm{n}$-hexane was purified using Sep-Pak Vac Cartridges Silica (Waters) and subsequently analysed by HPLC, as described previously (Hiraishi et al., 1996).
Cellular fatty acids were analysed after culture on trypticase soy agar for 2 days. The cellular fatty acids were saponified, methylated and extracted according to the protocol of the Sherlock Microbial Identification System (MIDI). The fatty acids were then analysed by GC (model 6890; Hewlett Packard) using the Microbial Identification software package (Sasser, 1990). Summed features, which are mixtures of two or three fatty acids, were analysed further using GC/MS.

The cellular fatty acid profiles of strain Gsoil $104^{\mathrm{T}}$ and related Pedobacter species are presented in Table 2. The major components were $\mathrm{C}_{16: 1} \omega 7 c$, iso- $\mathrm{C}_{15: 0}$, iso- $\mathrm{C}_{17: 0} 3$ $\mathrm{OH}$ and iso- $\mathrm{C}_{15: 0} 2-\mathrm{OH}$, which is a profile typical of members of the genus Pedobacter (Steyn et al., 1998). However, some differences in the proportions of the fatty acids could be observed between strain Gsoil $104^{\mathrm{T}}$ and the phylogenetically closest relatives. One of the major fatty acids found in strain Gsoil $104^{\mathrm{T}}$ was $\mathrm{C}_{16: 0}$ $(15.6 \%$ of total). This value is generally much higher than that reported for other Pedobacter species; only $P$. cryoconitis DSM $14825^{\mathrm{T}}(9 \cdot 1 \%)$ and $P$. himalayensis HHS $22^{\mathrm{T}}(7 \cdot 3 \%)$ have comparable levels of $\mathrm{C}_{16: 0}$. The DNA $\mathrm{G}+\mathrm{C}$ content for the genus Pedobacter ranges from $36.9 \mathrm{~mol} \%$ (reported for P. saltans) to $44.2 \mathrm{~mol} \%$ (reported for P. africanus) (Steyn et al., 1998). The G $+\mathrm{C}$ content of the DNA of strain Gsoil $104^{\mathrm{T}}$ was within this range $(43.6 \mathrm{~mol} \%)$. The predominant respiratory quinone of strain Gsoil $104^{\mathrm{T}}$ was MK-7.

To clarify the taxonomic position of strain Gsoil $104^{\mathrm{T}}$, DNA-DNA hybridization was performed with the four members of the genus most closely related to strain Gsoil $104^{\mathrm{T}}$. DNA-DNA hybridization was performed fluorometrically according to the method of Ezaki et al. (1989), using photobiotin-labelled DNA probes (Sigma) and microdilution wells (Greiner), with five replications for each sample. The highest and lowest values obtained for each sample were excluded and the means of the remaining three values are quoted as the DNA hybridization values. Strain Gsoil $104^{\mathrm{T}}$ exhibited relatively low levels of DNA-DNA relatedness with respect to $P$. africanus KACC $11389^{\mathrm{T}}(36 \%), P$. cryoconitis KACC $11394^{\mathrm{T}}(30 \%)$, P. caeni DSM $16990^{\mathrm{T}}$ $(25 \%)$ and P. heparinus DSM $2366^{\mathrm{T}}(19 \%)$, indicating that it is not related to them at the species level (Wayne et al., 1987).

The results obtained from the phenotypic and phylogenetic characterizations indicated that strain Gsoil $104^{\mathrm{T}}$ belongs to the genus Pedobacter. The phylogenetic distinctiveness of strain Gsoil $104^{\mathrm{T}}$, together with the DNA-DNA hybridization data, confirmed that this isolate represents a species that is distinct from recognized Pedobacter species. There are some phenotypic differences between strain Gsoil $104^{\mathrm{T}}$ and phylogenetically related Pedobacter species (Table 1). Therefore, on the basis of the data presented, strain Gsoil $104^{\mathrm{T}}$ should be classified within the genus Pedobacter as the type strain of a novel species, for which the name Pedobacter ginsengisoli sp. nov. is proposed. 
Table 1. Physiological and biochemical characteristics of strain Gsoil $104^{\top}$ and related Pedobacter species

Taxa: 1, strain Gsoil $104^{\mathrm{T}}$; 2, P. africanus; 3, P. caeni; 4, P. cryoconitis; 5, P. heparinus; 6, P. piscium; 7, P. himalayensis; 8, P. sandarakinus; 9, P. saltans. Data for reference species are from Steyn et al. (1998), Margesin et al. (2003), Shivaji et al. (2005), Vanparys et al. (2005) and Yoon et al. (2006). All taxa are positive for the following: aerobic growth, catalase, oxidase and utilization of D-mannose, D-glucose, $N$-acetyl-D-glucosamine, amygdalin (not done for P. himalayensis), D-lactose, D-melibiose (variable for $P$. saltans), sucrose (variable for $P$. saltans) and D-trehalose (variable for P. saltans) as sole carbon sources. All strains are negative for the following: Gram stain, sporulation, production of indole and $\mathrm{H}_{2} \mathrm{~S}$, urease, reduction of nitrate to nitrite and utilization of L-sorbose, D-lyxose (not done for $P$. himalayensis), D-fucose (not done for P. himalayensis), dulcitol, inositol, citrate, L-lysine (not done for P. sandarakinus), gluconate (not done for P. himalayensis), adipate (not done for P. himalayensis), caprate (not done for P. himalayensis), phenylacetate (not done for P. himalayensis) and malate as sole carbon sources. Symbols: +, positive; -, negative; V, variable; ND, no data available.

\begin{tabular}{|c|c|c|c|c|c|c|c|c|c|}
\hline Characteristic & 1 & 2 & 3 & 4 & 5 & 6 & 7 & 8 & 9 \\
\hline \multicolumn{10}{|l|}{ Enzyme activities } \\
\hline Gelatinase & - & $\mathrm{V}$ & - & + & - & - & + & - & - \\
\hline Lysine decarboxylase & - & + & ND & - & + & + & - & - & + \\
\hline Tryptophan deaminase & - & - & ND & - & - & ND & + & - & - \\
\hline Arginine dihydrolase & - & - & - & - & - & ND & + & - & - \\
\hline \multicolumn{10}{|l|}{ Acid production from: } \\
\hline D-Glucose & - & $\mathrm{V}$ & - & - & $\mathrm{V}$ & + & - & ND & $\mathrm{V}$ \\
\hline Sucrose & - & - & ND & - & - & + & - & ND & - \\
\hline D-Melibiose & - & - & ND & - & - & $\mathrm{V}$ & - & ND & - \\
\hline D-Mannitol & - & - & $\mathrm{ND}$ & + & - & $\mathrm{V}$ & + & ND & - \\
\hline Inositol & - & - & $\mathrm{ND}$ & - & - & - & + & ND & - \\
\hline D-Sorbitol & - & - & $\mathrm{ND}$ & - & $+^{*}$ & - & + & $\mathrm{ND}$ & - \\
\hline \multicolumn{10}{|l|}{ Utilization of: } \\
\hline D-Arabinose & - & - & - & - & - & - & + & - & $\mathrm{V}$ \\
\hline L-Arabinose & - & $\mathrm{V}$ & + & + & + & + & + & - & + \\
\hline D-Fructose & + & $\mathrm{V}$ & - & + & + & + & + & - & $\mathrm{V}$ \\
\hline D-Ribose & - & - & - & - & - & - & + & - & - \\
\hline D-Raffinose & + & - & + & + & - & + & + & - & $\mathrm{V}$ \\
\hline L-Rhamnose & - & + & - & - & + & $\mathrm{V}$ & + & - & + \\
\hline D-Xylose & + & $\mathrm{V}$ & - & + & + & + & + & - & + \\
\hline L-Xylose & + & - & + & - & - & - & + & - & - \\
\hline Starch & - & $\mathrm{V}$ & + & + & - & + & + & + & - \\
\hline Inulin & + & - & - & + & - & - & + & - & - \\
\hline Glycogen & - & - & - & + & - & - & - & + & - \\
\hline Adonitol & - & - & - & - & + & - & + & - & + \\
\hline Glycerol & + & - & - & - & - & - & + & - & + \\
\hline D-Mannitol & - & - & - & - & + & - & + & - & - \\
\hline D-Sorbitol & - & - & - & - & + & - & + & - & - \\
\hline Xylitol & - & - & + & - & - & - & - & - & - \\
\hline Pyruvate & - & $\mathrm{V}$ & $\mathrm{ND}$ & - & + & - & + & $\mathrm{ND}$ & - \\
\hline L-Alanine & - & $\mathrm{V}$ & ND & - & - & - & + & ND & - \\
\hline L-Aspartate & - & $\mathrm{V}$ & $\mathrm{ND}$ & + & - & - & + & $\mathrm{ND}$ & - \\
\hline L-Serine & - & + & ND & - & $\mathrm{V}$ & $\mathrm{V}$ & + & ND & - \\
\hline L-Glutamate & - & + & ND & - & - & + & + & ND & - \\
\hline DNA G $+\mathrm{C}$ content $(\mathrm{mol} \%)$ & $43 \cdot 6$ & $43 \cdot 7-44 \cdot 2$ & $42 \cdot 7$ & $43 \cdot 4$ & $42 \cdot 3-43 \cdot 0$ & $40 \cdot 4-41 \cdot 0$ & $41 \cdot 0$ & $39 \cdot 7$ & $36 \cdot 9-37 \cdot 1$ \\
\hline
\end{tabular}

${ }^{\star}$ Data from Takeuchi \& Yokota (1992).

\section{Description of Pedobacter ginsengisoli sp. nov.}

Pedobacter ginsengisoli (gin.sen.gi.so'li. N.L. n. ginsengum ginseng; L. n. solum soil; N.L. gen. n. ginsengisoli of soil from a ginseng field, the source of the type strain).
Cells are Gram-negative, aerobic, non-spore-forming, nonmotile and rod-shaped $(0 \cdot 5-1 \cdot 0 \times 2 \cdot 5-4.5 \mu \mathrm{m})$. After 6 days incubation at $25^{\circ} \mathrm{C}$ on $\mathrm{R} 2 \mathrm{~A}$, colonies are $2-5 \mathrm{~mm}$ in diameter, smooth, convex, round, glossy and white. Grows at $4-30{ }^{\circ} \mathrm{C}$; the optimum temperature for growth is $25^{\circ} \mathrm{C}$. The minimum $\mathrm{pH}$ for growth lies between $4 \cdot 5$ and 
Table 2. Fatty acid composition (\%) of strain Gsoil $104^{\top}$ and related Pedobacter species

Strains: 1, strain Gsoil $104^{\mathrm{T}}$; 2, P. africanus DSM $12126^{\mathrm{T}}$ (data from Steyn et al., 1998); 3, P. caeni LMG $22862^{\mathrm{T}}$ (Vanparys et al., 2005); 4, P. cryoconitis DSM $14825^{\mathrm{T}}$ (Shivaji et al., 2005); 5, P. heparinus DSM $2366^{\mathrm{T}}$ (Steyn et al., 1998); 6, P. piscium DSM $11725^{\mathrm{T}}$ (Steyn et al., 1998); 7, P. himalayensis HHS $22^{\mathrm{T}}$ (Shivaji et al., 2005); 8, P. sandarakinus KCTC $12559^{\mathrm{T}}$ (Yoon et al., 2006); 9, P. saltans DSM $12145^{\mathrm{T}}$ (Steyn et al., 1998). tr, Trace amount $(<1 \%) ;-$, not detected.

\begin{tabular}{|c|c|c|c|c|c|c|c|c|c|}
\hline Fatty acid & 1 & 2 & 3 & 4 & 5 & 6 & 7 & 8 & 9 \\
\hline \multicolumn{10}{|l|}{$\begin{array}{l}\text { Straight-chain } \\
\text { saturated }\end{array}$} \\
\hline $\mathrm{C}_{14: 0}$ & - & $1 \cdot 5$ & $2 \cdot 5$ & $1 \cdot 0$ & $1 \cdot 1$ & $1 \cdot 3$ & $1 \cdot 0$ & - & $\operatorname{tr}$ \\
\hline $\mathrm{C}_{15: 0}$ & - & $\operatorname{tr}$ & - & - & $1 \cdot 1$ & - & - & $4 \cdot 2$ & $1 \cdot 4$ \\
\hline $\mathrm{C}_{16: 0}$ & $15 \cdot 5$ & $3 \cdot 8$ & $3 \cdot 0$ & $9 \cdot 1$ & $3 \cdot 0$ & $3 \cdot 3$ & $7 \cdot 3$ & - & $4 \cdot 0$ \\
\hline $\mathrm{C}_{15: 0} 2-\mathrm{OH}$ & $1 \cdot 0$ & - & - & - & - & - & - & $1 \cdot 2$ & - \\
\hline $\mathrm{C}_{16: 0} 3-\mathrm{OH}$ & $2 \cdot 1$ & $3 \cdot 1$ & $2 \cdot 8$ & - & $1 \cdot 5$ & $4 \cdot 5$ & - & - & $\operatorname{tr}$ \\
\hline $\mathrm{C}_{17: 0} 2-\mathrm{OH}$ & $2 \cdot 9$ & - & $1 \cdot 3$ & - & - & - & - & - & - \\
\hline \multicolumn{10}{|l|}{$\begin{array}{l}\text { Branched } \\
\text { saturated }\end{array}$} \\
\hline iso- $\mathrm{C}_{15: 0}$ & $21 \cdot 5$ & $26 \cdot 6$ & $21 \cdot 3$ & $15 \cdot 0$ & $28 \cdot 22$ & $26 \cdot 23$ & $33 \cdot 0$ & $35 \cdot 8$ & $31 \cdot 4$ \\
\hline iso- $\mathrm{C}_{17: 0}$ & - & - & - & - & - & - & - & $1 \cdot 8$ & - \\
\hline iso- $\mathrm{C}_{15: 0} 2-\mathrm{OH}$ & $10 \cdot 9$ & $10 \cdot 4$ & $\mathrm{NA}^{*}$ & $2 \cdot 0$ & $10 \cdot 41$ & $10 \cdot 7$ & $2 \cdot 0$ & $\mathrm{NA}^{*}$ & $+8 \cdot 9$ \\
\hline iso- $\mathrm{C}_{15: 0} 3-\mathrm{OH}$ & I $3 \cdot 6$ & $2 \cdot 1$ & $3 \cdot 3$ & $1 \cdot 9$ & $2 \cdot 5$ & $2 \cdot 5$ & $1 \cdot 5$ & $3 \cdot 0$ & $2 \cdot 8$ \\
\hline iso- $\mathrm{C}_{16: 0} 3-\mathrm{OH}$ & $1 \cdot 1$ & - & - & - & - & - & - & - & - \\
\hline iso- $\mathrm{C}_{17: 0} 3-\mathrm{OH}$ & $13 \cdot 1$ & $14 \cdot 7$ & $12 \cdot 1$ & $4 \cdot 2$ & $15 \cdot 2$ & $9 \cdot 2$ & $6 \cdot 0$ & $17 \cdot 7$ & $12 \cdot 7$ \\
\hline anteiso- $\mathrm{C}_{15: 0}$ & $1 \cdot 2$ & $\operatorname{tr}$ & $\operatorname{tr}$ & - & $\operatorname{tr}$ & $2 \cdot 6$ & - & - & $2 \cdot 9$ \\
\hline $\begin{array}{l}\text { Summed } \\
\text { feature } 3 \dagger\end{array}$ & - & - & $39 \cdot 9$ & - & - & - & - & $21 \cdot 7$ & - \\
\hline \multicolumn{10}{|l|}{ Monounsaturated } \\
\hline $\mathrm{C}_{15: 1} \omega 6 c$ & - & $\operatorname{tr}$ & - & - & - & - & - & $1 \cdot 6$ & $1 \cdot 4$ \\
\hline $\mathrm{C}_{16: 1} \omega 5 c$ & - & $2 \cdot 1$ & $2 \cdot 5$ & - & $1 \cdot 4$ & $3 \cdot 5$ & - & - & $\operatorname{tr}$ \\
\hline $\mathrm{C}_{16: 1} \omega 7 c$ & $23 \cdot 3$ & $23 \cdot 7$ & $\mathrm{NA}^{*}$ & $+27 \cdot 02$ & $20 \cdot 23$ & $31 \cdot 42$ & $20 \cdot 0$ & $\mathrm{NA}^{*}$ & $+19 \cdot 6$ \\
\hline $\mathrm{C}_{17: 1} \omega 8 c$ & - & - & - & - & - & - & - & $1 \cdot 1$ & - \\
\hline iso- $\mathrm{C}_{17: 1} \omega 9 c$ & $2 \cdot 4$ & $4 \cdot 4$ & $2 \cdot 2$ & $8 \cdot 6$ & $6 \cdot 3$ & $1 \cdot 6$ & $4 \cdot 0$ & $3 \cdot 8$ & $6 \cdot 6$ \\
\hline $\begin{array}{l}\text { anteiso- } \\
\mathrm{C}_{17: 1} \omega 9 c\end{array}$ & - & - & $\operatorname{tr}$ & - & - & $1 \cdot 2$ & - & - & - \\
\hline \multicolumn{10}{|l|}{ Unknown } \\
\hline ECL $13 \cdot 566$ & - & $2 \cdot 6$ & - & - & $5 \cdot 0$ & $\operatorname{tr}$ & - & - & $1 \cdot 1$ \\
\hline ECL $13 \cdot 961$ & $1 \cdot 4$ & - & - & - & - & - & - & - & - \\
\hline ECL $16 \cdot 580$ & - & $1 \cdot 0$ & - & - & $1 \cdot 0$ & $\operatorname{tr}$ & - & - & $1 \cdot 2$ \\
\hline
\end{tabular}

${ }^{\star}$ Not applicable (fatty acids are components of unresolved summed feature 3).

$\dagger$ Summed features represent groups of two or three fatty acids that could not be separated by GLC with the MIDI system. Summed feature 3 contained iso- $\mathrm{C}_{15: 0} 2-\mathrm{OH}$ and/or $\mathrm{C}_{16: 1} \omega 7 c$.

$\ddagger$ Unknown fatty acids have no name listed in the peak library file of the MIDI system and therefore cannot be identified. ECL, Equivalent chain length.

$5 \cdot 0$, the optimum $\mathrm{pH}$ is $6 \cdot 5-7 \cdot 5$ and the maximum $\mathrm{pH}$ lies between $8 \cdot 5$ and $9 \cdot 0$. Tolerates $1 \%(\mathrm{w} / \mathrm{v}) \mathrm{NaCl}$, but not $2 \%$. Growth occurs on trypticase soy agar, but not on
MacConkey agar. Positive for catalase and oxidase, but negative for lipase. Negative for hydrolysis of chitin, starch, cellulose, xylan, casein and aesculin and positive for hydrolysis of DNA. The following substrates are utilized for growth: D-glucose, D-galactose, D-mannose, D-fructose, D-xylose, L-xylose, $N$-acetyl-D-glucosamine, salicin, Dcellobiose, D-lactose, D-maltose, D-melibiose, sucrose, Dtrehalose, D-raffinose, amygdalin, glycerol, inulin and dextran. The following substrates are not utilized for growth: D-arabinose, L-arabinose, D-fucose, ethanol, Lrhamnose, L-sorbose, D-lyxose, D-ribose, pyruvate, formate, acetate, propionate, DL-3-hydroxybutyrate, valerate, caprate, maleate, fumarate, phenylacetate, benzoate, 3-hydroxybenzoate, 4-hydroxybenzoate, citrate, lactate, malate, malonate, succinate, glutarate, tartrate, itaconate, adipate, suberate, oxalate, gluconate, dulcitol, inositol, D-adonitol, D-mannitol, D-sorbitol, xylitol, methanol, glycogen, Lalanine, L-arginine, L-asparagine, L-aspartic acid, L-cysteine, L-glutamic acid, L-glutamine, L-histidine, glycine, L-isoleucine, L-leucine, L-lysine, L-methionine, L-phenylalanine, L-proline, L-serine, L-threonine, L-tryptophan, L-tyrosine and L-valine. In API 20E tests, the Voges-Proskauer test is positive and tests for arginine dihydrolase, lysine decarboxylase, ornithine decarboxylase, tryptophan deaminase, urease, gelatinase, $\beta$-galactosidase and production of hydrogen sulphide and indole are all negative. Acid is not produced from D-glucose, D-melibiose, amygdalin, Larabinose, D-mannitol, inositol, D-sorbitol, L-rhamnose or sucrose. The major fatty acids are $\mathrm{C}_{16: 1} \omega 7 c$, iso- $\mathrm{C}_{15: 0}, \mathrm{C}_{16: 0}$, iso- $\mathrm{C}_{17: 0} 3-\mathrm{OH}$ and iso- $\mathrm{C}_{15: 0} 2-\mathrm{OH}$. The $\mathrm{G}+\mathrm{C}$ content of the genomic DNA is $43.6 \mathrm{~mol} \%$. The predominant respiratory quinone is MK-7.

The type strain, Gsoil $104^{\mathrm{T}}\left(=\right.$ KCTC $12576^{\mathrm{T}}=\mathrm{LMG}$ $23399^{\mathrm{T}}$ ), was isolated from a soil sample from a ginseng field in Pocheon Province (South Korea).

\section{Acknowledgements}

This work was supported by the Brain Pool Program (grant 031-4-17) funded by the Ministry of Science and Technology and by the 2006 research program of the Rural Development Administration, Republic of Korea.

\section{References}

Atlas, R. M. (1993). Handbook of Microbiological Media. Edited by L. C. Parks. Boca Raton, FL: CRC Press.

Buck, J. D. (1982). Nonstaining (KOH) method for determination of Gram reactions of marine bacteria. Appl Environ Microbiol 44, 992-993.

Ezaki, T., Hashimoto, Y. \& Yabuuchi, E. (1989). Fluorometric DNADNA hybridization in microdilution wells as an alternative to membrane filter hybridization in which radioisotopes are used to determine genetic relatedness among bacterial strains. Int $J$ Syst Bacteriol 39, 224-229.

Felsenstein, J. (1985). Confidence limits on phylogenies: an approach using the bootstrap. Evolution 39, 783-791. 
Fitch, W. M. (1971). Toward defining the course of evolution: minimum change for a specific tree topology. Syst Zool 20, 406-416.

Gallego, V., García, M. T. \& Ventosa, A. (2006). Pedobacter aquatilis sp. nov., isolated from drinking water, and emended description of the genus Pedobacter. Int J Syst Evol Microbiol 56, 1853-1858.

Hall, T. A. (1999). BioEdit: a user-friendly biological sequence alignment editor and analysis program for Windows 95/98/NT. Nucleic Acids Symp Ser 41, 95-98.

Hiraishi, A., Ueda, Y., Ishihara, J. \& Mori, T. (1996). Comparative lipoquinone analysis of influent sewage and activated sludge by highperformance liquid chromatography and photodiode array detection. J Gen Appl Microbiol 42, 457-469.

Hwang, C. Y., Choi, D. H. \& Cho, B. C. (2006). Pedobacter roseus sp. nov., isolated from a hypertrophic pond, and emended description of the genus Pedobacter. Int J Syst Evol Microbiol 56, 1831-1836.

Im, W.-T., Jung, H.-M., Cui, Y.-S., Liu, Q.-M., Zhang, S.-L. \& Lee, S.-T. (2005). Cultivation of three hundred bacterial species from the soil of the ginseng field and mining the novel lineage bacteria. In Proceedings of the International Meeting of the Federation of Korean Microbiological Societies, abstract A035, p. 169. Seoul: Federation of Korean Microbiological Societies.

Kim, M. K., Im, W.-T., Ohta, H., Lee, M. \& Lee, S.-T. (2005). Sphingopyxis granuli sp. nov., a $\beta$-glucosidase-producing bacterium in the family Sphingomonadaceae in $\alpha-4$ subclass of the Proteobacteria. J Microbiol 43, 152-157.

Kimura, M. (1983). The Neutral Theory of Molecular Evolution. Cambridge: Cambridge University Press.

Kouker, G. \& Jaeger, K.-E. (1987). Specific and sensitive plate assay for bacterial lipases. Appl Environ Microbiol 53, 211-213.

Kumar, S., Tamura, K. \& Nei, M. (2004). MEGA3: integrated software for molecular evolutionary genetics analysis and sequence alignment. Brief Bioinform 5, 150-163.

Margesin, R., Spröer, C., Schumann, P. \& Schinner, F. (2003). Pedobacter cryoconitis sp. nov., a facultative psychrophile from alpine glacier cryoconite. Int J Syst Evol Microbiol 53, 1291-1296.

Mesbah, M., Premachandran, U. \& Whitman, W. B. (1989). Precise measurement of the $\mathrm{G}+\mathrm{C}$ content of deoxyribonucleic acid by highperformance liquid chromatography. Int J Syst Bacteriol 39, 159-167.

Moore, D. D. \& Dowhan, D. (1995). Preparation and analysis of DNA. In Current Protocols in Molecular Biology, chapter 2. Edited by F. M. Ausubel, R. Brent, R. E. Kingston, D. D. Moore, J. G. Seidman, J. A. Smith \& K. Struhl. New York: Wiley.

Saitou, N. \& Nei, M. (1987). The neighbor-joining method: a new method for reconstructing phylogenetic trees. Mol Biol Evol 4, 406-425.

Sasser, M. (1990). Identification of bacteria by gas chromatography of cellular fatty acids. MIDI Technical Note 101. Newark, DE: MIDI.

Shivaji, S., Chaturvedi, P., Reddy, G. S. N. \& Suresh, K. (2005). Pedobacter himalayensis sp. nov., from the Hamta glacier located in the Himalayan mountain ranges of India. Int J Syst Evol Microbiol 55, $1083-1088$
Stackebrandt, E. \& Goebel, B. M. (1994). Taxonomic note: a place for DNA-DNA reassociation and 16S rRNA sequence analysis in the present species definition in bacteriology. Int J Syst Bacteriol 44, 846-849.

Stackebrandt, E., Frederiksen, W., Garrity, G. M. \& 10 other authors (2002). Report of the ad hoc committee for the re-evaluation of the species definition in bacteriology. Int J Syst Evol Microbiol 52, 1043-1047.

Steyn, P. L., Segers, P., Vancanneyt, M., Sandra, P., Kersters, K. \& Joubert, J. J. (1998). Classification of heparinolytic bacteria into a new genus, Pedobacter, comprising four species: Pedobacter heparinus comb. nov., Pedobacter piscium comb. nov., Pedobacter africanus sp. nov. and Pedobacter saltans sp. nov. Proposal of the family Sphingobacteriaceae fam. nov. Int J Syst Bacteriol 48, 165-177.

Takeuchi, M. \& Yokota, A. (1992). Proposals of Sphingobacterium faecium sp. nov., Sphingobacterium piscium sp. nov., Sphingobacterium heparinum comb. nov., Sphingobacterium thalpophilum comb. nov., and two genospecies of the genus Sphingobacterium, and synonymy of Flavobacterium yabuuchiae and Sphingobacterium spiritivorum. J Gen Appl Microbiol 38, 465-482.

Ten, L. N., Im, W.-T., Kim, M.-K., Kang, M.-S. \& Lee, S.-T. (2004). Development of a plate technique for screening of polysaccharidedegrading microorganisms by using a mixture of insoluble chromogenic substrates. J Microbiol Methods 56, 375-382.

Thompson, J. D., Gibson, T. J., Plewniak, F., Jeanmougin, F. \& Higgins, D. G. (1997). The CLUSTAL_X windows interface: flexible strategies for multiple sequence alignment aided by quality analysis tools. Nucleic Acids Res 25, 4876-4882.

Tschech, A. \& Pfennig, N. (1984). Growth yield increase linked to caffeate reduction in Acetobacterium woodii. Arch Microbiol 137, 163-167.

Vanparys, B., Heylen, K., Lebbe, L. \& De Vos, P. (2005). Pedobacter caeni sp. nov., a novel species isolated from a nitrifying inoculum. Int J Syst Evol Microbiol 55, 1315-1318.

Wayne, L. G., Brenner, D. J., Colwell, R. R. \& 9 other authors (1987). International Committee on Systematic Bacteriology. Report of the ad hoc committee on reconciliation of approaches to bacterial systematics. Int J Syst Bacteriol 37, 463-464.

Widdel, F. \& Bak, F. (1992). Gram-negative mesophilic sulfatereducing bacteria. In The Prokaryotes, 2nd edn, pp. 3352-3378. Edited by A. Balows, H. G. Trüper, M. Dworkin, W. Harder \& K. H. Schleifer. New York: Springer.

Widdel, F., Kohring, G. \& Mayer, F. (1983). Studies on dissimilatory sulfate-reducing bacteria that decompose fatty acids. III. Characterization of the filamentous gliding Desulfonema limicola gen. nov. sp. nov., and Desulfonema magnum sp. nov. Arch Microbiol 134, 286-294.

Yoon, J.-H., Lee, M.-H., Kang, S.-J., Park, S.-Y. \& Oh, T.-K. (2006). Pedobacter sandarakinus sp. nov., isolated from soil. Int J Syst Evol Microbiol 56, 1273-1277. 